\title{
Glutathione Contents in Rat Livers after Acute and Chronic Exposure to Ethylene Oxide
}

\author{
Kayoko NaKashima', Aki Furutani ${ }^{1}$, Ken Higashi ${ }^{1, *}$, Fumio OKUnO ${ }^{2}$ \\ and Naohide INOUE ${ }^{3}$ \\ 'Departments of Biochemistry, School of Medicine, University of Occupational and Environmental Health, \\ Japan. Kitakyushu 807, Japan \\ ${ }^{2}$ First Department of Internal Medicine, School of Medicine; University of Occupational and Environmental Health, \\ Japan. Kitakyushu 807, Japan \\ ${ }^{3}$ Department of Environmental Toxicology, Institute of Industrial Ecological Sciences, University of Occupational \\ and Environmental Health, Japan. Kitakyushu 807, Japan
}

\begin{abstract}
Wistar rats were subjected to a $6 \mathrm{hr}$ exposure to ethylene oxide once at the concentration of 500 ppm, 3 times a week for 12 weeks as a chronic experiment. Hepatic glutathione contents were determined after these treatments. The specific content of reduced form of glutathione (GSH) in the rat livers of chronic exposures was 28.9 nmoles $/ \mathrm{mg}$ protein, which is not significantly different from that of control group. On the other hand, the hepatic content of GSH in rats subjected to a $4 \mathrm{hr}$ exposure to ethylene oxide at a concentration of $2500 \mathrm{ppm}$ decreased markedly to the levels of $5 \%$ of control value. The present results suggest the involvement of glutathione, at least in part, in the detoxication of ethylene oxide.
\end{abstract}

Key words : ethylene oxide, glutathione, rat liver, detoxication.

(Reseived 11 August 1987)

\section{Introduction}

Ethylene oxide is a colorless gas used mainly to sterilize medical equipment, or as a precursor for industrial chemicals (Rose, 1983). Many workers around the world are exposed to ethylene oxide (Hine et al., 1981). Ethylene oxide has shown a strong mutagenic potential (Landrigan et al., 1984) in various organisms such as Drosophila (Fahmy \& Fahmy, 1970), barley (Rapoport, 1948), and Neurospora crassa (K $\phi$ lmark \& Westergaad, 1953), as well as in the Ames test (Environmental Protection Agency, 1978). Recently, we have reported the first animal model of ethylene oxide-induced neuropathy in a chronic exposure experiment (Ohnishi et al., 1985). It is of interest to know how ethylene oxide becomes metabolized in the animal body and what effect ethylene oxide or its metabolites has on normal metabolic functions of the whole body. Previously, we reported on the possible metabolites of ethylene oxide, that is, hydroxyethyl-mercapturic acid which is produced after conjugation with glutathione (Koga et al., 1984). In the present study, we observed the rapid exhaustion of glutathione in the rat livers after an acute exposure to ethylene oxide.

${ }^{*}$ To whom all correspondence should be addressed. 
This observation supports our previous proposal that glutathione might be involved in the detoxication of ethylene oxide.

\section{Methods}

Twenty-four male Wistar rats weighing about $170 \mathrm{~g}$ were divided into 2 groups. Twelve rats were subjected to $6 \mathrm{hr}$ exposure to ethylene oxide at a concentration of 500 parts per million (ppm), 3 times a week for 12 weeks. Exposure systems were identical to those reported previously (Ohnishi et al., 1986). Food and water were not given to the rats during the exposure. Another 12 rats, exposed to filtered room air introduced into a chamber, were pair-fed and served as end-controls. In the acute exposure experiment, six rats were exposed to ethylene oxide once at the concentration of $2500 \mathrm{ppm}$ for $4 \mathrm{hr}$. Rats were sacrificed immediately after this acute exposure. Reduced glutathione (GSH) contents in the acid-soluble fractions prepared from individual rat livers were determined separately according to the method described by Saville (1958) with slight modifications (Tateishi et al., 1980). Protein contents in the initial homogenates of individual rat livers were determined by the procedure of Lowry et al. (1951).

\section{Results and Discussion}

In the chronic-exposure experiment, the average body weight of rats was $458 \mathrm{~g}$ for control group and $269 \mathrm{~g}$ for treated group $(P<0.001)$, and the average liver weight was $10.1 \mathrm{~g}$ for control group and $6.2 \mathrm{~g}$ for treated group $(P<0.001)$, respectively (Table 1). Although mean weights of both bodies and livers of the treated group were smaller than those of control group, GSH content per $\mathrm{g}$ of liver in the treated group $(7.13 \mu$ moles $)$ was greater than that of control group $(5.43 \mu$ moles $)(P<0.005)$. However, the specific content of GSH (nmoles/mg protein) in the treated rat livers did not significantly differ from that of control group (Table 1). Recently we observed that if the same amounts of food were given to the rats of the control and treated groups, there was no difference in GSH content per $g$ of

Table 1. Hepatic glutathione contents in chronic exposure experiment

\begin{tabular}{|c|c|c|c|c|c|c|}
\hline \multirow{2}{*}{$\begin{array}{l}\text { No. of } \\
\text { determi- } \\
\text { nations }^{\dagger}\end{array}$} & \multirow{2}{*}{$\begin{array}{l}\text { Body } \\
\text { weight } \\
(\mathrm{g})\end{array}$} & \multirow{2}{*}{$\begin{array}{l}\text { Liver } \\
\text { weight } \\
\text { (g) }\end{array}$} & \multirow{2}{*}{$\begin{array}{c}\text { Protein } \\
\text { content } \\
(\mathrm{mg} / \mathrm{g} \text { liver })\end{array}$} & \multicolumn{3}{|c|}{ Glutathione content } \\
\hline & & & & (mg/g liver) & ( $\mu \mathrm{mol} / \mathrm{g}$ liver $)$ & (nmol/mg protein) \\
\hline \multicolumn{7}{|l|}{ Control } \\
\hline 12 & $458 \pm 31^{\S}$ & $10.1 \pm 0.3$ & $210.8 \pm 10.3$ & $1.67 \pm 0.05$ & $5.43 \pm 0.16$ & $26.2 \pm 1.1$ \\
\hline \multicolumn{7}{|l|}{ Exposure } \\
\hline 12 & $269^{*} \pm 42$ & $6.2^{*} \pm 0.3$ & $248^{* *} \pm 4.1$ & $2.20^{*} \pm 0.22$ & $7.13^{* *} \pm 0.22$ & $28.9 \pm 1.2$ \\
\hline
\end{tabular}

\footnotetext{
† Values were determined separately for individual livers.

$\S$ Standard error.

${ }^{*} P<0.001, \quad * * P<0.005$.
} 
Table 2. Hepatic glutathione contents in acute exposure experiment

\begin{tabular}{lcccccc}
\hline $\begin{array}{l}\text { No. of } \\
\text { determi- } \\
\text { nations }\end{array}$ & $\begin{array}{c}\text { Body } \\
\text { weight } \\
(\mathrm{g})\end{array}$ & $\begin{array}{c}\text { Liver } \\
\text { weight } \\
(\mathrm{g})\end{array}$ & $\begin{array}{c}\text { Protein } \\
\text { content } \\
(\mathrm{mg} / \mathrm{g} \text { liver })\end{array}$ & & \multicolumn{3}{c}{ Glutathione content } \\
\cline { 6 - 7 } $\begin{array}{l}\text { Control } \\
6\end{array}$ & $230 \pm 2^{\S}$ & $9.7 \pm 0.3$ & $316.2 \pm 9.7$ & $1.95 \pm 0.06$ & $6.35 \pm 0.25$ & $20.2 \pm 0.9$ \\
$\begin{array}{c}\text { Exposure } \\
6\end{array}$ & $232 \pm 4$ & $8.5 \pm 0.3$ & $354.8 \pm 5.8$ & $0.12^{* *} \pm 0.01$ & $0.39^{*} \pm 0.03$ & $1.1^{* *} \pm 0.09$ \\
\hline
\end{tabular}

† Values were determined separately for individual livers.

$\S$ Standard error.

$* P<0.001, \quad * * P<0.005$.

liver between them. (Okuno et al., unpublished results).

On the contrary, hepatic GSH contents in the ethylene oxide-treated group in the acute exposure experiment decreased remarkably as shown in Table 2. Both GSH content per $g$ of tissue and specific content of GSH per $\mathrm{mg}$ protein in the treated group reduced remarkably to the levels of approximately $5 \%$ of control $(P<0.005)$.

The major pathway of ethylene oxide metabolism in the rat involves conjugation of this epoxide with glutathione (Jones \& Wells, 1981). We also examined the metabolites of ethylene oxide in the urine of rats after subacute exposure and identified one component as hydroxyethylmercapturic acid-derivative, which was detected only in the treated group (Koga et al., 1984). The reactions of glutathione with electrophilic compounds, such as epoxides, are promoted by glutathione S-transferases. In many cases, the conjugates are transformed to mercapturic acid by enzymes, for example, $\gamma$-glutamyltranspeptidase and cysteinylglycinase succeeded by an $\mathrm{N}$-acetylation (Kosower, 1978).

Although we determined only the reduced form of glutathione, glutathione depletion reflected a loss of total glutathione and not a conversion to oxidized glutathione, since hepatic concentration of the latter is always less than $0.15 \mathrm{mM}$ (Kosower, 1978; Mitchel et al., 1973). Recently, Mckelvey and Zemaitis (1986) have reported on the effects of acute ethylene oxide exposure on tissue glutathione levels in rats and mice. They observed that levels of oxidized form of glutathione in the lung, testis and liver were either unaffected or decreased after ethylene oxide exposure.

Glutathione serves an intracellular protective role by reacting with electrophiles to prevent interactions between these reactive electrophiles and essential cellular proteins and nucleic acids. Glutathione content per $\mathrm{g}$ of liver in the chronic exposure group with a relatively low dose of ethylene oxide may compensate for the loss of glutathione due to conjugate with ethylene oxide. The apparent increase of glutathione content per $\mathrm{g}$ of liver in the chronic experiment (Table 1) was partially due to the decrease of both body and liver weights in the exposure group. As described in the results of chronic experiments, the glutathione content per $\mathrm{g}$ of liver in the chronic exposure group did not show any increase when compared with those of control animals whose body weights were regulated to the 
levels of the exposure group by giving limited amounts of foods (Okuno et al., unpublished data). The present study is compatible with the earlier report on the effects of acute ethylene oxide exposure on the glutathione content of rat tissues (Mckelvey \& Zemaitis, 1986) and also the first report on the compensation of the loss of glutathione content in chronic exposure experiment.

This work was supported in part by a special grant by the Ministry of Labor for Occupational Health Studies in 1987.

\section{References}

Environmental Protection Agency (1978): Ethylene oxide. Federal Register. 43. pp. 3800-3815.

Fahmy, O. G. \& Fahmy, M. J. (1970): Gene elimination in carcinogenesis: Reinterpretation of the somatic mutation theory. Cancer Res., 30: 195-205.

Hine, C. H., Rowe, V. K., Darmer, K. I. et al. (1981): Ethylene Oxide. In: Industrial Hygiene and Toxicology. Vol. II . (Clayton, G. D. \& Clayton, E. E., ed.). A Wiley-Interscience Publ., New York. pp. $2166-2186$.

Jones, A. R. \& Wells, G. (1981): The comparative metabolism of 2-bromoethanol and ethylene oxide in the rat. Xenobiotica, 11 (11): 763-770.

K $\phi$ lmark, G. \& Westergaad, M. (1953): Further studies on chemically induced reversions at the adenine locus of Neurospora. Hereditas, 39: 209-224.

Koga, M., Shinohara, R., Hori, H. et al. (1984): Identification of metabolites by the urine of rats exposed to ethylene oxide. Igaku-no-Ayumi, 128: 303-305. (in Japanese)

Kosower, N. S. (1978): The glutathione status of cells. In: International Review of Cytology. Vol. 54. (Bourne, G. H. \& Danielli, J. F., ed.). Academic Press, New York. pp. 109-160.

Landrigan, P. J., Meinhardt, T. J., Gordon, J. et al. (1984): Ethylene oxide: An overview of toxicologic and epidemiologic research. Am. J. Ind. Med., 6: 103-115.

Lowry, O. H., Rosebrough, N. J., Farr, A. L. el al. (1951): Protein measurement 'with the Folin phenol reagent. J. Biol. Chem., 193: 265-275.

Mckelvey, J. A. \& Zemaitis, M. A. (1986): The effects of ethylene oxide (EO) exposure on tissue glutathione levels in rats and mice. Drug Chem. Toxicol., $9(1): 51-66$.

Mitchel, J. R., Jollow, D. J., Potter, W. Z. et al. (1973): Acetaminophen-induced hepatic necrosis. IV. Protective role of glutathione. J. Pharmacol. Exp. Ther., 187: 211-217.

Ohnishi, A., Inoue, N., Yamamoto, T. et al. (1985): Ethylene oxide induces centralperipheral distal axonal degeneration of the lumbar primary neurones in rats. Br. J. Ind. Med., 42: 373-379.

Ohnishi, A., Inoue, N., Yamamoto, T. et al. (1986): Ethylene oxide neuropathy in rats exposure to $250 \mathrm{ppm}$. J. Neurol. Sci., 74: 215-221.

Rapoport, I. A. (1948): Action of ethylene oxide, glycidol and glycols on gene mutation. Dokl. Akad. Nauk. SSSR, 60: 469-472.

Rose, V. E. (1983): Ethylene oxide. In: Encyclopedia of Occupational Health and Safety. Vol. 1. (Parmeggiani, L. ed.). International Labour Organization, Geneva. pp. 797-799.

Saville, B. (1958): A scheme for the colorimetric determination of microgram amounts of thiols. Analyst, 83: $670-672$.

Tateishi, N., Higashi, T., Nakashima, K. et al. (1980): Nutritional significance of increase in

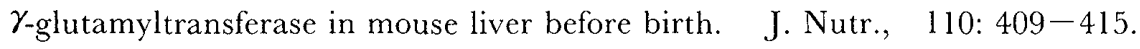




\section{ラット肝グルタチオン含量に対する急性㧍よび慢性酸化エチレン暴露の影響}

中鴆加代子 ${ }^{1} \cdot$ 古谷 垔紀 ${ }^{1}$ 東 監 ${ }^{1}$ 奥野 府夫 ${ }^{2}$ 井上 尚英 ${ }^{3}$

産業医科大学生化学教室 2 产業医科大学第一内科学教室

3産業医科大学産業生態科学研究所環境中毒学教室

要旨： 慢性実験ではラットを $500 \mathrm{ppm}$ の酸化エチレンに 6 時間ずつ週 3 回, 12 週間暴露し， 対照群と共に，還元型肝グルタチオン含量を測った。慢性暴露群では，肝グルタチオン含 量は，28.9 nmoles/mg protein で，対照群のそれと差はなかった，一方，酸化エチレン $2500 \mathrm{ppm}$ の濃度に 4 時間暴露した急性群では肝グルタチオン含量は対照群の $5 \%$ 位に減 少した。これらの結果から，酸化エチレンの代謝の少なくとも一部はグルタチオン抱合が 関与していることが示唆された.

J. UOEH (産業医大誌), -9 (4):355-359 (1987) 